Archiv für die gesamte Virusforschung 33, 88-98 (1971)

(C) by Springer-Verlag 1971

\title{
The Distribution of Neuraminidase among the Cytoplasmic Membranes of HeLa Cells Infected with an Influenza Virus
}

\author{
By \\ A. P. Kendal, F. Biddle, and K. Apostolov \\ Department of Bacteriology, University College Hospital Medical School, \\ London, England, \\ Welleome Research Laboratories, Park Langley, \\ Beckenham, Kent, England \\ With 2 Figures
}

Received May 29, 1970

\section{Summary}

1. The post-mitochondrial fraction of HeLa cells infected with influenza virus was sub-fractionated by density gradient flotation centrifugation.

2. $74-95 \%$ of the neuraminidase activity recovered from this density gradient was shown to be associated with five species of cell material, that (a) were obtained initially in gradient fractions with buoyant densities of 1.100, 1.137, $1.176,1.203$ and $>1.203 \mathrm{gm} / \mathrm{cm}^{3}$; (b) subsequently sedimented at $70,000 \times g$ for 1 hour in the absence of a density gradient; (c) were rich in membranes when examined in the electron microscope.

3. It is concluded that neuraminidase in the cytoplasm of influenza-infected HeLa cells is predominantly membrane bound.

4. The neuraminidase specific activity of fractions rich in smooth membranes was equal to or greater than the specific activity of fractions rich in rough endoplasmic reticulum. It is suggested therefore that the smooth membranes may be responsible for the transport of neuraminidase through the cytoplasm of influenzainfected cells.

\section{Introduction}

Myxoviruses are characteristic in possessing an enzyme, neuraminidase (E.C.3.2.1.18) in their coat. As neuraminidase may be accurately quantitated by means of its enzymic activity, neuraminidase therefore provides an ideal model with which to investigate directly the production and transport of myxovirus components within infected cells. Of particular interest is the relationship between myxovirus components and intracellular membranes in infected cells, since cell membrane is incorporated into the viral envelope during maturation of newly synthesized virions (see HoYLE, 1968). The major problem in undertaking such a study is the need to reproducibly isolate recognizable cell membrane fractions, but recently a method has been described for HeLa cells which enables some 
cell membrane species to be purified (Bosmann, Hagortan and Eylar, 1968). Although the infectious cycle of influenza virus in HeLa cells is abortive (HENLE, GIRARDT and HENLE, 1955) synthesis of viral nucleic acid occurs to a similar extent in influenza-infected HeLa cells as in permissive cells where a full yield of virus is obtained (LERNer and Hodge, 1969). Additionally, we have previously shown that neuraminidase may be detected on HeLa cells monolayers infected with influenza virus (KENDAI and APOstolov, 1970), and we have therefore now attempted to determine the distribution of neuraminidase in the cytoplasm and membranes of HeLa cells infected with an influenza virus.

\section{Materials and Methods}

\subsection{Cell Growth}

A mycoplasma-free HeLa cell line $\left(\right.$ ref $\left.\mathrm{CCl}_{2}\right)$ was initially obtained from the American Type Culture Collection (Rockville, Maryland), and monolayers were grown at $37^{\circ} \mathrm{C}$ in $10 \mathrm{oz}$. rolling bottles, seeded at $5 \times 10^{6}$ cells $/$ bottle. Cell growth medium was either Eagle's minimal medium (Wellcome), or Eagle's minimal medium containing $4 \%$ glutamine (Flow laboratories), supplemented in both cases with $10 \%$ calf serum (Flow laboratories). Confluent cell monolayers (about $20 \times 10^{6}$ cells $/$ bottle) were washed twice with $0.15 \mathrm{M}$ sodium chloride, and infected with about $160 \times 10^{\circ}$ median egg infectious virus doses in $50 \mathrm{ml}$ of Eagle's minimal medium (Wellcome).

The virus strain was the recombinant influenza X-7 (FI) (KILBoURNE et al., 1967), seed of which was kindly provided by Dr. G. Schild of the National Institute for Medical Research, London. After the required time of incubation at $37^{\circ} \mathrm{C}$, the cell maintenance medium was discarded, the cell monolayers washed twice with $0.15 \mathrm{~m}$ sodium chloride, and the cells then detached from the glass bottles by treating with $10 \mathrm{ml}$ of 0.02 per cent EDTA solution at $37^{\circ} \mathrm{C}$ for 15 minutes, and then agitating gently.

\subsection{Cell Fractionation}

Cells from 10 bottles were pooled, pelleted at $400 \times g$ for 5 minutes (M.S.E. minor centrifuge) and washed 3 times with $30 \mathrm{ml}$ volumes of chilled $0.15 \mathrm{M}$ sodium chloride containing $10^{-3} \mathrm{M}$ calcium acetate. Finally the cells were pelleted and resuspended in $3 \mathrm{ml}$ of chilled THE buffer $(0.02 \mathrm{M}$ Tris/HCl $\mathrm{pH} 7.0$, containing $0.01 \mathrm{M}$ EDTA). They were immediately disrupted by standard technique in a glass barrel tissue homogenizer using a tight-fitting teflon pestle (Jencon Ltd.), cooled in melting ice. Optimum cell breakage consistent with the recovery of intact nuclei was seen by phase contrast microscopy to occur after about 60 strokes by hand. Homogenized preparations were centrifuged at $4,000 \times g$ for 10 minutes (Spinco $L I$ ), and the pellet containing undisrupted cells, nuclei, and most of the mitochondria, was discarded. The supernatant was made $45 \% \mathrm{w} / \mathrm{w}$ with sucrose, and the volume adjusted to $7 \mathrm{ml}$ with $45 \%$ $\mathrm{w} / \mathrm{w}$ sucrose in THE buffer. This was placed at the bottom of a $20 \mathrm{ml}$ transparent polycarbonate centrifuge tube, and then overlayed with $4.3 \mathrm{ml}$ of $35 \% \mathrm{w} / \mathrm{w}$ sucrose, $4.3 \mathrm{ml}$ of $25 \% \mathrm{w} / \mathrm{w}$ sucrose, and $3.3 \mathrm{ml}$ of $25 \% \mathrm{w} / \mathrm{w}$ sucrose, all in THE buffer. Finally. the gradient was overlayed with $1 \mathrm{ml}$ of THE buffer, and centrifuged at $70,000 \times g$ for 17 hours at $+5^{\circ} \mathrm{C}$ in the $3 \times 23 \mathrm{ml}$ swinging bucket rotor of the M.S.E. superspeed 65 centrifuge. This fractionation procedure is based on the method of BosmanN et al. (1968), scaled down for use with a smaller number of cells.

\subsection{Determinations}

Neuraminidase activity was determined by incubating at $37^{\circ} \mathrm{C}$ for 17 hours reaction mixtures containing in $1.1 \mathrm{ml}$ volumes $0.6 \mu \mathrm{M}$ of NAN-LAC substrate (Bovine $\mathrm{N}$-acetylneuraminyl-lactose, purified as described by KENDAL, BIDDLe and BeLYavin, 1968 ), and either $1.0 \mathrm{ml}$ of fraction $\mathrm{S}_{1}-\mathrm{S}_{5}{ }^{1}$ or $0.01-0.1 \mathrm{ml}$ of fraction $P_{1}-P_{5}{ }^{1}$, the volume being made up to $1.1 \mathrm{ml}$ with neuraminidase buffer. Free $\mathrm{N}$-acetylneura-

1 See results. 
minic acid (NANA) released by neuraminidase was determined by the automated thiobarbituric acid method (KENDAL, 1968).

Protein was estimated by the Lowry method, as described by LEGGET-BaILey (1962).

Buoyant density of fractions 1-4 recovered from the density gradient was determined from refractive index measurements, made with an Abbé refractometer.

\subsection{Electron Microscopy}

Electron Microscopy was performed on the residual membrane fractions $P_{1}-P_{5}{ }^{2}$ left after removing sample aliquots. The corresponding fractions from 5 experiments were pooled, and then pelleted, fixed, embedded, stained (with uranyl acetate and lead citrate), sectioned and examined as described previously (KENDaL, APOSTolov and Bexpavin, 1969).

\section{Results}

3.1. Density Gradient Flotation Centrifugation of HeLa Cell Post-mitochondrial Fraction

As described in Methods, the post-mitochondrial fraction of homogenized HeLa cells was sub-fractionated by density gradient flotation. Three opalescent bands

\section{Fraction}

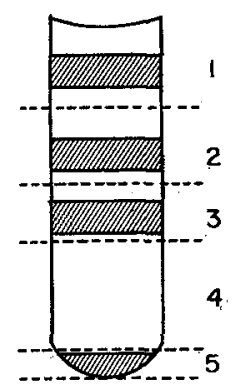

Fig. 1. Representation of appearance of centrifuge tube after density gradient flotation of HeLa cell post- mitochondrial fraction

Fractions obtained from above by pipette are indicated by dotted lines. Note that after fraction 4 was diluted and then centrifuged at $70,000 \times g$ for 1 hour, a membrane pellet $\left(P_{4}\right)$ was also recovered from this fraction, making a total of 5 membrane fractions in all. For full experimental details, see text

were always visible in the density gradient, as shown in Fig. 1, and these were recovered by pipette together with their surrounding layers of the density gradient as fractions I, 2 and 3 . Additionally, the translucent layer (fraction 4) corresponding to the initial position of the sample prior to centrifugation was recovered from just above the pellet, which was also always present. The mean buoyant densities of fractions $1-4$ were $1.100,1.137,1.176$ and $1.203 \mathrm{gm} / \mathrm{cm}^{3}$, respectively. Fraetions $1-4$ were diluted to $20 \mathrm{ml}$ with neuraminidase buffer $(0.1 \mathrm{M}$ phosphate pH 6.8 containing $0.02 \%$ sodium azide), and the pellet was also resuspended in $20 \mathrm{ml}$ of this buffer, as fraction 5. Each of the 5 diluted fractions was then centrifuged at $70,000 \times g$ for 1 hour to sediment high molecular weight material. Not only was the opalescent material in fractions 1,2 and 3 recovered in this way as pellets, as was the original resuspended pellet forming fraction 5 , but additionally a pellet was obtained from fraction 4 . The pellets thus obtained from fractions $1-5$ were resuspended in $1 \mathrm{ml}$ volumes of neuraminidase buffer, and designated as $P_{1}-P_{5}$. The supernatants from this step were dialyzed against several changes of neuraminidase buffer to remove sucrose, and then designated as $S_{1}$ -

\footnotetext{
2 See results.
} 
Table 1. Distribution of Protein in HeLa Cell Fractions

\begin{tabular}{lcc}
\hline Fraction & $\mu g$ protein/fraction & $\begin{array}{l}\text { Per cent total protein } \\
\text { recovered }\end{array}$ \\
\hline $\mathrm{P}_{1}$ & 157 & 1.6 \\
$\mathrm{P}_{2}$ & 183 & 1.9 \\
$\mathrm{P}_{3}$ & 300 & 3.1 \\
$\mathrm{P}_{4}$ & 372 & 3.9 \\
$\mathrm{P}_{5}$ & 127 & 1.3 \\
$\mathrm{~S}_{1}$ & 390 & 4.1 \\
$\mathrm{~S}_{2}$ & 226 & 2.9 \\
$\mathrm{~S}_{2}$ & 1,700 & 17.8 \\
$\mathrm{~S}_{4}$ & 5,500 & 58.0 \\
$\mathrm{~S}_{5}$ & 515 & 5.4 \\
\hline Total & 9,470 & 100 \\
\hline
\end{tabular}

1 Mean values from 3 experiments.

Table 2. Association of Neuraminidase Activity with Membrane-rich Fractions of Influenza-infected HeLa Cells

\begin{tabular}{|c|c|c|c|c|}
\hline \multirow[t]{2}{*}{$\begin{array}{l}\text { Hours } \\
\text { post-infection }\end{array}$} & \multicolumn{2}{|c|}{$\begin{array}{l}\text { Combined supernatants } \\
\left(\mathbf{S}_{1}-\mathbf{S}_{5}\right)\end{array}$} & \multicolumn{2}{|c|}{$\begin{array}{l}\text { Combined pellets } \\
\left(\mathbf{P}_{1}-\mathbf{P}_{6}\right)\end{array}$} \\
\hline & Activity ${ }^{1}$ & Per cent total & Activity & Per cent total \\
\hline 6 & 80 & 5 & 1,400 & 95 \\
\hline 12 & 18,000 & 18 & 83,000 & 82 \\
\hline 72 & 3,900 & 26 & 11,000 & 74 \\
\hline
\end{tabular}

${ }^{1} \mathrm{n}$ Moles of NAN-LAC hydrolyzed/17 hours by combined fractions.

All results are the mean from duplicate experiments.

Table 3. Distribution of Neuraminidase Activity among the Membrane-rich Fractions from Influenza-infected HeLa Cells

\begin{tabular}{|c|c|c|c|c|c|}
\hline \multirow{2}{*}{$\begin{array}{l}\text { Time } \\
\text { post } \\
\text { infection } \\
\text { (hours) }\end{array}$} & \multicolumn{5}{|c|}{ Cell fraction } \\
\hline & $P_{1}$ & $\mathrm{P}_{2}$ & $P_{s}$ & $P_{4}$ & $P_{5}$ \\
\hline 6 & $116^{1}$ & 390 & 485 & 375 & 40 \\
\hline 12 & 15,500 & 23,000 & 22,500 & 17,400 & 4,800 \\
\hline 72 & 3,000 & 1,700 & 3,100 & 2,600 & 600 \\
\hline
\end{tabular}

${ }^{1}$ n Moles NAN-LAC hydrolyzed/17 hours/fraction.

All results are the mean of duplicate experiments.

Table 4. Neuraminidase Specific Activities of Membrane-rich Fractions from Influenza-infected HeLa Cells

\begin{tabular}{rlllll}
\hline $\begin{array}{l}\text { Time } \\
\text { post } \\
\text { infection } \\
\text { (hours) }\end{array}$ & \multicolumn{1}{l}{ Cell fraction } & & & & \\
\cline { 2 - 6 } & $\mathrm{P}_{1}$ & $\mathrm{P}_{2}$ & $\mathrm{P}_{3}$ & $\mathrm{P}_{\mathrm{a}}$ & $\mathrm{P}_{5}$ \\
\hline 6 & $2.6^{\mathrm{x}}$ & 3.0 & 2.3 & 1.3 & 0.5 \\
12 & 176 & 105 & 62 & 42 & 32 \\
72 & 26 & 21 & 20 & 23 & 5.5 \\
\hline
\end{tabular}

${ }^{1}$ n Moles NAN-LAC hydrolyzed/17 hours/ug protein.

All results are the mean of duplicate experiments. 


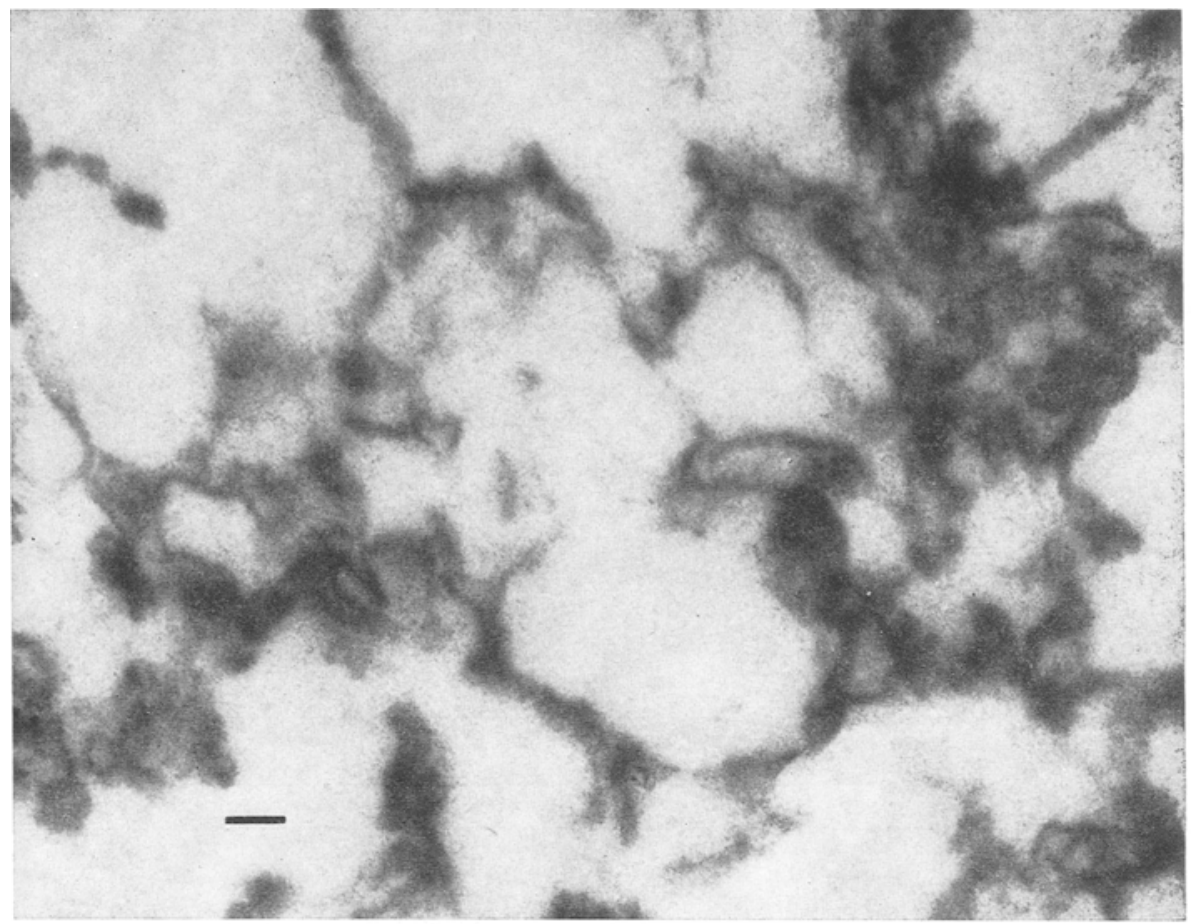

Fig. 2a

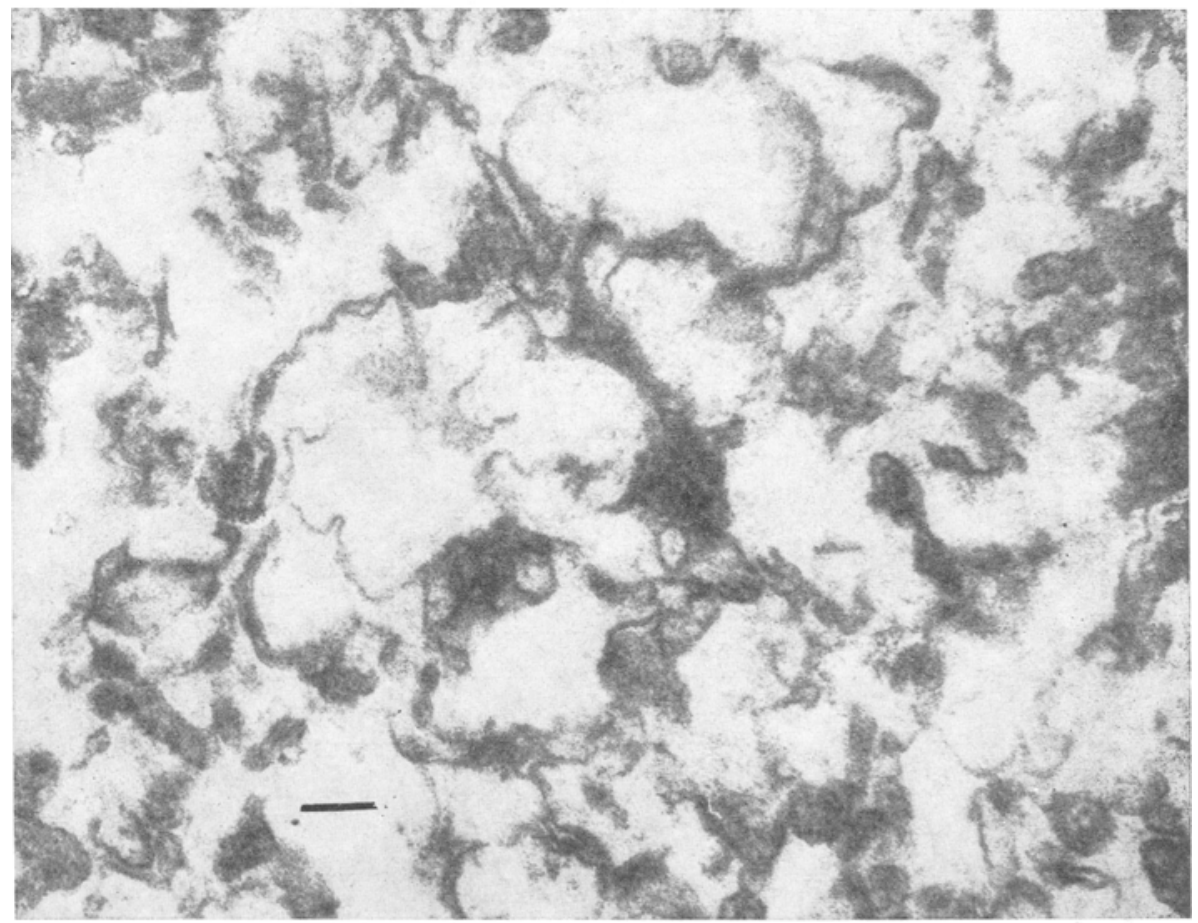

Fig. 2b 
$\mathrm{S}_{5}$. Table 1 shows the distribution of protein in the final fractions $\mathbf{P}_{\mathbf{1}}-\mathbf{P}_{\mathbf{5}}$ and $S_{1}-S_{5}$ from which it can be seen that the majority of the protein recovered from the original density gradient had remained in the initial sample layer 4 and the adjacent fraction 3. Most of this protein was soluble, and stayed in the supernatant fractions $S_{3}$ and $S_{4}$ after centrifugation of the fractions 3 and 4 at $70,000 \times g$ for 1 hour. The amount of protein sedimentable at $70,000 \times g$ for 1 hour and found in the fractions $P_{1}-P_{5}$ represented a very small proportion of the total recovered.

\subsection{Electron Microscopy of the Fraction $P_{1}-P_{5}$}

When observed in the electron microscope, these fractions were found to be rich in membranes (Fig. 2). Fractions $\mathbf{P}_{\mathbf{1}}, \mathbf{P}_{\mathbf{2}}$ and $\mathbf{P}_{\mathbf{3}}$ contained predominantly smooth membranes, with no indication of ribosomal material, whereas fraction $\mathrm{P}_{4}$ contained rough endoplasmic reticulum, and some polysomes. The membranes of fraction $P_{5}$ are believed to be derived from the cell plasma membrane (BosMANN et al., 1967). However, our preparation was contaminated with many free ribosomes.

\subsection{Association of Neuraminidase Activity with Fractions $\mathbf{P}_{1}-\mathbf{P}_{5}$}

The neuraminidase activity of fractions $P_{1}-P_{5}$ and $S_{1}-S_{5}$ was determined at 3 different times after infection of HeLa cells with influenza virus X-7 (FI). Tables 2,3 and 4 summarize the significant features of these results. Of the total neuraminidase activity recovered from the cell post-mitochondrial fraction after density gradient flotation centrifugation, $74-95 \%$ was associated with the membrane-rich fractions $\mathrm{P}_{1}-\mathrm{P}_{5}$ (Table 2). However, the distribution of this enzymic activity among these fractions was not uniform. Consistently, large amounts of neuraminidase were found in fractions $P_{1}, P_{2}$ and $P_{3}$, which did not appear to contain ribosomal material, as well as fraction $\mathrm{P}_{4}$ which was rich in rough endoplasmic reticulum. This observation was apparent both from the distribution of total neuraminidase activity (Table 3 ) and the neuraminidase specific activity of the fractions (Table 4). Equally consistently, these analyses showed that less than $5 \%$ of the recovered neuraminidase activity was found in fraction $P_{5}$. This latter finding demonstrates that neuraminidase present in the post-mitochondrial fraction of influenza-infected HeLa cells does not form membranefree protein aggregates, since such aggregated material would have been recovered in fraction $P_{5}$ under the experimental conditions adopted bere.

\section{Discussion}

In our application of Bosmann's technique for isolating HeLa cell membranes (Bosmann et al., 1968), we have also attempted to identify the total distribution of protein in the cell post-mitochondrial fraction after density gradient flotation. As shown in Table 1, about $75 \%$ of this protein was recovered in subfractions $S_{4}$ and $S_{3}$, obtained from the initial sample layer at the base of the gradient (fraction 4) and the adjacent fraction 3. Thus, the cell post-mitochondrial 
A. P. Kendal, F. Biddle, and K. Apostolov:

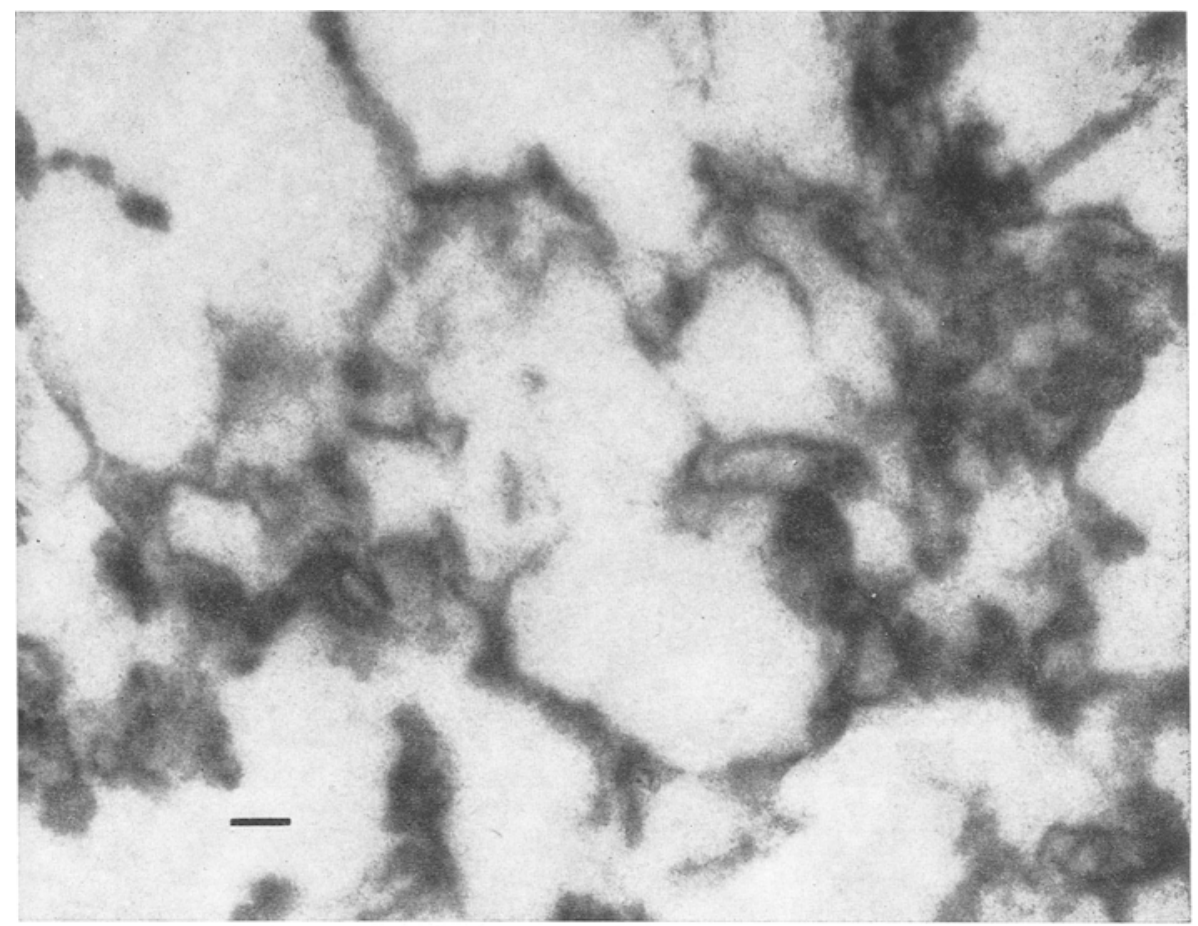

Fig. 2a

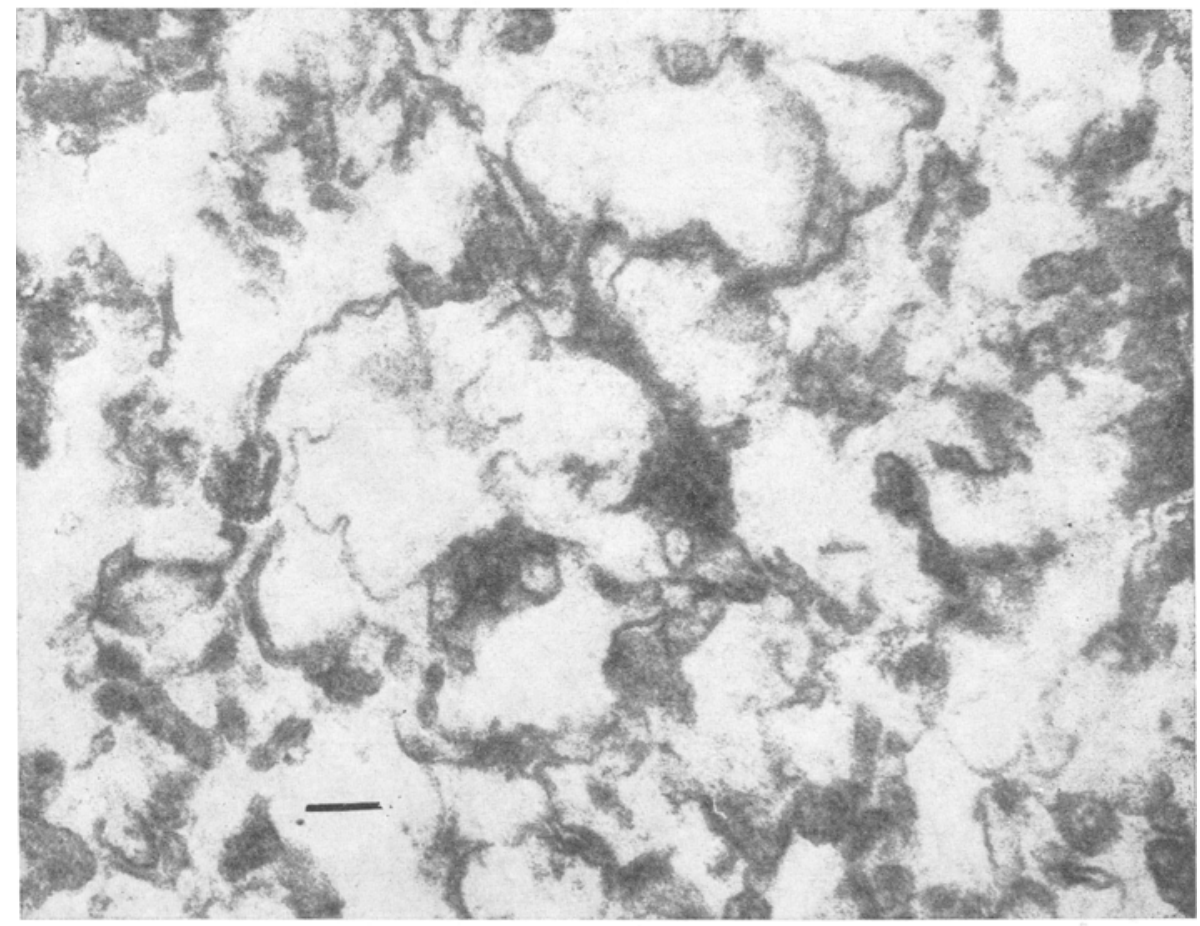

Fig. 2b 


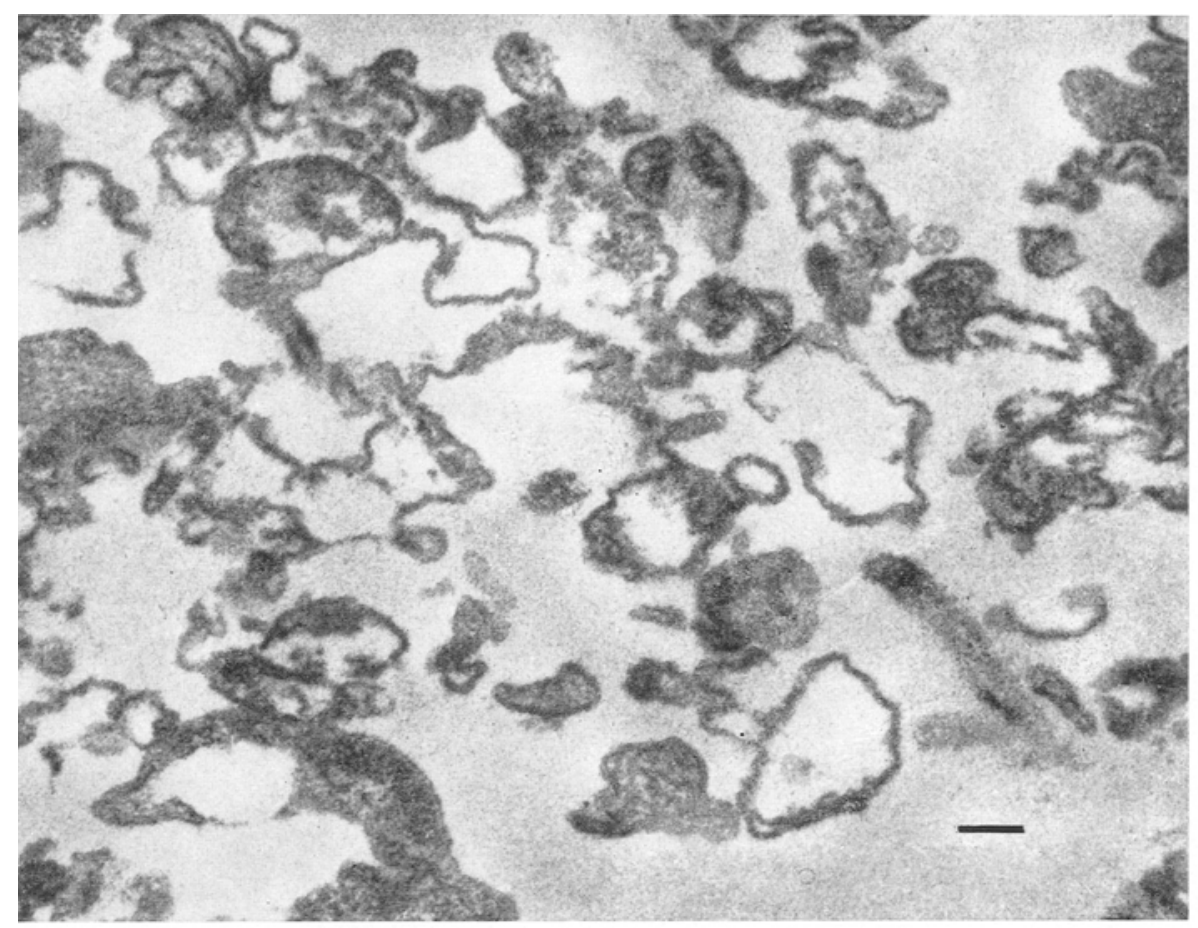

Fig. 2c

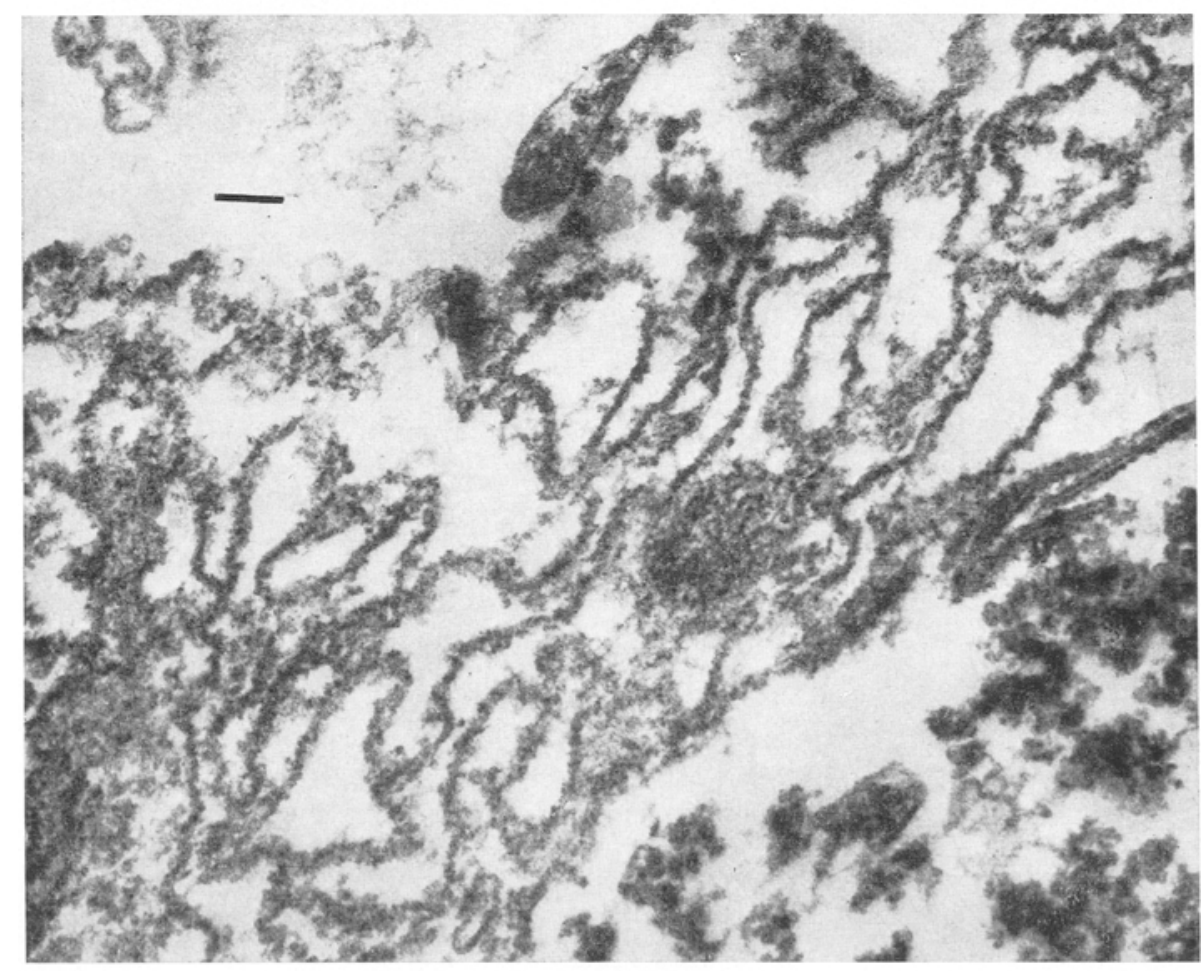


fraction was essentially resolved into 6 sub-fractions of major relevance here, comprising the 5 membranerich sub-fractions $P_{1}-P_{5}$, and sub-fractions $S_{3}$ and $S_{4}$ which together contained the bulk of the cell post-microsomal supernatant proteins.

Electron microscopy of the fractions $P_{1}-P_{5}$ showed that the three fractions of lowest buoyant density $\left(P_{1}, P_{2}\right.$ and $\left.P_{3}\right)$ were rich in predominantly smooth membrane, whereas fraction $\mathrm{P}_{4}$ was rich in rough endoplasmic reticulum and polysomes. These findings are generally consistent with those of BosmanN et al. (1968), although absolute correlation is not possible since Bosmann identified 7 membrane fractions in all. A quite similar distribution of membrane-rich fractions to ours has been obtained from HEp-2 cells by SPEAR, KrLLER and RorzMAN (1970), using fundamentally the same techniques, and these latter authors also showed that the bulk of the proteins in the cell post-mitochondrial fraction was soluble and remained in the sample layer during density gradient flotation. To facilitate future comparison of the membranes obtained by different workers, however, it would seem advantageous to characterize some easily determined property, such as the buoyant density of the membranes.

Measurement of the neuraminidase activity of the fractions obtained in the present experiments showed that at least $70 \%$ of the enzyme recovered from the cell post-mitochondrial fraction was associated with membrane-rich material of low buoyant density, (Fractions $P_{1}-P_{4}, p \leqslant 1.203 \mathrm{gm} / \mathrm{cm}^{3}$ ) but could be sedimented at $70,000 \times g$ for 1 hour in the absence of a density gradient. It is therefore concluded that neuraminidase synthesized in influenza-infected HeLa cells is predominantly in a membrane bound form. However, the present results do not indicate whether the molecules of neuraminidase have a strong non-specific affinity for lipoprotein membranes, or are actually incorporated into them to form ordered stable complexes similar to those of matured virions.

In an attempt to investigate the transport of neuraminidase in the cell cytoplasm, the neuraminidase specific activity of the different membrane-rich fractions was determined at different times post-infection. At all times, enzymic activity was found in fraction $\mathrm{P}_{4}$, that contained rough endoplasmic reticulum. However, even at 6 hour post-infection similar amounts of neuraminidase were also associated with the 3 smooth membrane fractions, which did not appear to contain ribosomes. The most probable explanation for this is that synthesis of neuraminidase began in a ribosomal fraction earlier than 6 hours post-infection, so that by this time the newly-synthesized enzyme had already begun to distribute throughout the cells. At longer times post-infection the neuraminidase specific activity of the smooth membrane fraction $P_{1}$ became greater than any of the other fractions, and these findings are in agreement with the possibility that viral components are transported to the cell plasma membrane by movement of internal cytoplasmic membranes. Although it cannot be entirely excluded that the association of neuraminidase with smooth membranes is passive, and not a requirement for viral replication, the low level of soluble neuraminidase activity within the cytoplasm is not in favor of simple diffusion being the major factor in spreading the enzyme throughout cells.

It was hoped that some insight would be gained into the relative amounts of neuraminidase on the cell plasma membrane and in the cell cytoplasm following 
infection. However, although BosmanN et al. (1968) reported that the pellet recovered after density gradient flotation centrifugation of the post-mitochondrial cell fraction could be taken as a good source of plasma membrane, we found this fraction ( $\mathrm{P}_{5}$ in the present experiment) to be contaminated with many free ribosomes. The presence of this ribosomal protein in fraction $P_{5}$ might explain in part the low neuraminidase specific activity of this fraction. Since it has been suggested that one factor contributing to the abortive infectious cycle of influenza virus in HeLa cells may be the inability of the plasma membrane to participate in a maturation reaction (KwNDAL and APosToLov, 1970), we have also looked at the distribution of neuraminidase on the membranes of influenzainfected calf-kidney cells, which support the productive infection by influenza. Using the same techniques as applied here, the distribution of enzymic activity was found to be qualitatively'similar in these cells to HeLa cells (BIDDLE, Apostolov and KendaL, unpublished observation).

Whether intracellular neuraminidase has any function during the cycle of infection by influenza viruses is still a subject of speculation. Thus, it remains to be shown whether the presence of intracellular viral neuraminidase is required to prevent viral haemagglutinin binding to intracellular sialic acid receptors, in the same way as extracellular bacterial neuraminidase appears to help liberate virions from extracellular receptors (Compans, DIMmock and MEIER-Ewert, 1969). Additionally, the binding of enzymically active neuraminidase to intracellular membranes could have profound effects on the physico-chemical and metabolic function of those membranes.

Attempts to measure the neuraminidase activity of the nuclear and mitochondrial pellet obtained from homogenized HeLa cells were unsuccessful, due to the interference by 2-deoxy-sugar in the estimation of free sialic acid (WARREN, 1959).

\section{Acknowledgements}

The mycoplasma-free HeLa cell line was kindly supplied by Miss M. Griffiths, of U.C.H.M.S., and auto-analyzer equipment was generously loaned by the Technicon Instruments Co. We are also grateful to Mr. S. Squires of May \& Baker Ltd., Dagenham, for assistance in the preparation of sialo-lactose. A. P. Kendal was supported by a grant from the Science Research Council.

\section{References}

1. Bosmann, H. B., A. Hagopian, and E. H. Erlar: Cellular membranes: The isolation and characterisation of the plasma and smooth membranes of HeLa cells. Arch. Biochem. 128, 51-69 (1968).

2. Compans, R. W., N. J. Dimmock, and H. Meier-Ewert : Effect of antibody to neuraminidase on the maturation and hemagglutinating activity of an Influenza $\mathrm{A}_{2}$ virus. J. Virol. 4, 528-534 (1969).

3. Henle, G., A. GIRARd, and W. Henle: A non-transmissible cytopathogenic effect of influenza virus in tissue culture accompanied by formation of non-infeetious haemagghutinins. J. exp. Med. 101, 25-41 (1955).

4. Horle, L.: In: Virology Monographs, IV; The Influenza Viruses. pp. $137-138$, Wien - New York: Springer, 1968.

5. Kendal, A. P.: Automation of a thiobarbituric acid assay for sialic acid. In: Automation in Analytical Chemistry, Technicon Symposium 1967. Vol. II, pp. 175-181, New York: Mediad Inc., 1968. 
6. Kendal, A. P., and K. Apostolov: The production of neuraminidase in cell monolayers infected with influenza virus. Nature (Lond.) 226, 167-168 (1970).

7. KENDAL, A. P., K. APOSTOLOV, and G. BEL Xavin : The effect of protease treatment on the morphology of Influenza A, B and C viruses. J. gen. Virol, $5,141-143$ (1969).

8. Kendal, A. P., F. BIdDLe, and G. Belyavin: Influenza virus neuraminidase and the viral surface. Biochim. biophys. Acta (Amst.) 165, 419-431 (1968).

9. Kirbourne, E. D., F. S. Lief, J. L. SchulmaN, R. I. Jahiel, and W. G. Laver: Antigenic hybrids of Influenza viruses and their implications, In: Perspectives in Virology. 5, 87-106, N.Y.: Academic Press, 1967.

10. Legget-Barly, J.: In: Techniques in Protein Chemistry, p. 293, Amsterdam: Elsevier, 1962.

11. LERNER, R. A., and L. D. HoDGE: Nonpermissive infections of mammalian cells: Synthesis of Influenza virus genome in HeLa cells. Proe. nat. Acad. Sci. (Wash.) 64, 544-551 (1969).

12. Spear, Patricia G., J. M. Keller, and B.' Rolzman: Proteins specified by Herpes simplex virus. II. Viral glycoproteins associated with cellular membranes. J. Virol. 5, 123-131 (1970).

13. WARREN, L.: The thiobarbituric acid assay of sialic acids. J. biol. Chem. 234, $1971-1975$ (1959).

Authors' address: Dr. A. P. KENDAL, Department of Epidemiology, School of Public Health, University of Michigan, Ann Arbor, MI 48104, U.S.A. 